XII. On a new genus and species of Noctuidae from Britain. By Sir George F. Hampson, Bart., F.Z.S., etc.

[Read October 6, 1909.]

\title{
Plate XVI.
}

\section{Genus Peucephila, nov.}

\section{Type, P. essoni.}

Proboscis fully developed; pulpi obliquely upturned, the second joint extending to about middle of frons and fringed with long hair in front, the third short; frons smooth; eyes large, round, strongly hairy, not overhung by cilia ; antennae of female ciliated ; head and thorax thickly clothed with hair and hair-like scales, the prothorax with large, sharp, triangular crest; the metathorax with spreading crest; tibiae fringed with hair above and without spines; abdomen with dorsal series of hairy crests. Fore-wing with the apex rectangular, the termen evenly curved, crenulate; veins, 3 and 5 from near angle of cell ; 6 from upper angle; 9 from 10 anastomosing with 8 to form the areole; 11 from cell. Hind-wing with veins 3.4 from angle of cell; 5 obsolescent from middle of discocellulars ; 6.7 from upper angle ; 8 anastomosing with the cell near base only.

\section{Peucephila essoni, sp. n.}

․ Head and thorax grey mixed with dark brown; antennae whitish ; abdomen flesh-pink, greyish at base, the crests dark brown mixed with grey; palpi, pectus, and ventral surface of abdomen flesh-pink; legs brownish ochreous, the tarsi with fuscous bands. Fore-wing flesh-pink tinged with brown, the costal area suffused with grey-white leaving the costal edge pinkish, the veins streaked with grey-white, the terminal area whitish with pinkish patches in the interspaces, especially towards apex; traces of a waved brown subbasal line from costa to submedian fold ; ante-medial line blackish at costa, then indistinct, brown, oblique, sinuous; claviform small, blackish filled in with grey scales; orbicular and reniform greywhite defined by blackish, incompletely above and below, the former small, round, the latter somewhat quadrate and with some fleshcolour in its upper part; traces of a sinuous dark medial line

TRANS. ENT. SOC, LOND, 1909.-PART IV. (DEC.) 
oblique from costa to reniform and inwardly oblique from lower angle of cell to inner margin; postmedial line blackish, bent outwards below costa, then obsolescent, dentate and produced to short black streaks on the veins, excurved to vein 4 , then oblique; subterminal line whitish, obsolescent towards costa and dentate to termen at veins $4: 3$, some dark suffusion before it; cilia pink with slight whitish line at middle and whitish tips. Hind-wing ochreous white with a slight fuscous tinge at upper angle of cell, short postmedial black streaks on veins 7 to 2 , and a fuscous tinge on subterminal area between veins 4 and 2 ; cilia tinged with reddish ochreous except at tips. Underside of both wings ochreous white, the costal and terminal areas strongly tinged with flesh-pink, a postmedial series of short black streaks on the veins.

Hab. Scotland, Aberdeen (L. G. Esson), 1 q type. Exp. 40 mill. vII.

The unique female was taken at sugar in July of this year on the trunk of a pine in a pine-wood eight miles from Aberdeen by Mr. L. G. Esson, a most energetic and careful naturalist, who is to be much congratulated on his interesting discovery, and who, it is to be hoped, will next year turn up other specimens of this fine addition to the British fauna. The specimen is obviously only just emerged from the pupa, and its coloration irresistibly suggests that it habitually rests on the trunks of pine-trees. It belongs to the Hadeninae, the hairy-eyed subfamily of the Noctuae trifinae, and is a development from Perigrapha and Monima (Taeniocampa), differing from both in having a dorsal series of abdominal crests and from the latter in having a sharp triangular pro-thoracic crest; from Miselia (Mamestra) it differs in having the sharp triangular prothoracic crest and its hairy scaling; in coloration it somewhat reminds one of Panolis flammea. Apart from its structure there does not seem to be any British species of which it could possibly be an aberration, whilst the specimen itself has no appearance of abnormality. The suggestion that it is a hybrid between two genera, of which Miselia would be one and some form with sharp pro-thoracic crest and hairy scaling the other parent appears to me much more improbable than that a new British Noctua should be discovered, and I conclude that the species is either indigenous or perhaps imported, probably in the egg stage on some exotic conifer; I have, however, failed to find any described species from any part of the 
a new genus and species of Noctuidae from Britain. 463

world to which it could belong, and have worked up the whole group in vol. $\mathbf{v}$ of the British Museum Catalogue of Moths. The type has been kindly purchased by the Hon. L. W. and N. C. Rothschild and presented to the British Museum.

Explanation of Plate XVI.

[See Explanation facing the Plate.] 



\section{$2 \mathrm{BHL}$ Biodiversity Heritage Library}

Hampson, George Francis. 1909. "XII. On a new genus and species of Noctuidae from Britain." Transactions of the Entomological Society of London 57, 461-464. https://doi.org/10.1111/j.1365-2311.1909.tb02180.x.

View This Item Online: https://www.biodiversitylibrary.org/item/51003

DOI: https://doi.org/10.1111/j.1365-2311.1909.tb02180.x

Permalink: https://www.biodiversitylibrary.org/partpdf/37258

\section{Holding Institution}

Smithsonian Libraries

\section{Sponsored by}

Smithsonian

\section{Copyright \& Reuse}

Copyright Status: Public domain. The BHL considers that this work is no longer under copyright protection.

This document was created from content at the Biodiversity Heritage Library, the world's largest open access digital library for biodiversity literature and archives. Visit BHL at https://www.biodiversitylibrary.org. 